\title{
NUTRIENT, PHYTOCHEMICAL AND SENSORY EVALUATION OF BISCUITS PRODUCED FROM COMPOSITE FLOURS OF WHEAT ENRICHED WITH OKRA POD
}

\author{
Amadi, Joy A.C \\ Department of Nutrition and Dietetics, Imo State University P.M.B. 2000, Owerri, Nigeria. \\ Email: joyamadi@imsu.edu.ng +2347030987007
}

\begin{abstract}
The study evaluated the nutrient, phytochemical and sensory evaluation of biscuits made from composite flours of wheat and okra pod for enrichment. Wheat flour, fresh okra pods and all ingredients used in biscuit making were purchased from Relief market Owerri, Imo State. The okra pod was washed, sliced into pieces, oven dried at $60^{\circ} \mathrm{C}$ for 8 hours and milled into flour. The biscuits were formulated as 100\% wheat flour (WF), 80\% wheat flour : 20\% okra pod flour (WOF1), 70\% wheat flour :30\% okra pod flour (WOF2) and 60\% wheat flour:40\% okra pod flour (WOF3). Chemical and sensory analysis was carried using standard methods. Results were expressed using means and standard deviation using SPSS. Biscuit WOF3 had the highest moisture $(13.56 \pm 1.16 \%)$, ash $(3.49 \pm 0.01 \%)$ and protein $(14.99 \pm 1.38 \%)$ contents, while biscuit WF recorded the highest fat $(15.68 \pm 0.22 \%)$, crude fiber $(2.73 \pm 0.05 \%)$, carbohydrate $(63.03 \pm 0.32 \%)$ and energy $(439.08 \pm 2.93 \%)$ contents. The mineral composition shows that biscuit WOF3 recorded the highest calcium $(212.50 \pm 0.010 \mathrm{mg} / 100 \mathrm{~g})$, magnesium $(83.50 \pm 0.009 \mathrm{mg} / 100 \mathrm{~g})$, potassium $(594.00 \pm 0.00 \mathrm{mg} / 100 \mathrm{~g})$ and manganese $(1457.00 \pm 0.24 \mathrm{mg} / 100 \mathrm{~g})$, while biscuit WOF1 had highest iron $(109.12 \pm 0.88 \mathrm{mg} / 100 \mathrm{~g})$ and copper $(23.00 \pm 0.42 \mathrm{mg} / 100 \mathrm{~g})$. The anti-nutrients revealed that biscuit WOF1 was highest tannin content $(0.22 \pm 0.025 \mathrm{mg} / 100 \mathrm{~g})$, biscuit WOF2 had the highest phenol content $(1.41 \pm 0.001$ $\mathrm{mg} / 100 \mathrm{~g})$, while biscuit WOF2 had the highest oxalate content $(1.06 \pm 0.082 \mathrm{mg} / 100 \mathrm{~g})$. The sensory scores of the enriched biscuits shows biscuit WF3 rated best in aroma (5.46 \pm 1.63$)$, colour (4.66 \pm 1.68$)$ and taste $(5.54 \pm 1.69)$ and general acceptability (5.94 \pm 1.73$)$, biscuit WOF rated best in crispness (4.66 \pm 1.89$)$ while biscuit WOF2 rated best in texture (5.18 \pm 1.68$)$. The study revealed that acceptable biscuit of high nutritional content could be produced.
\end{abstract}

Keywords: Okra, wheat, biscuit, enrichment

https://dx.doi.org/10.4314/jafs.v17i1.5

\section{INTRODUCTION}

Protein-energy malnutrition (PEM) and micronutrient deficiency is still a major public health problem in developing countries especially in Nigeria (Oshionya et al., 2015; WPF, 2011). This 
public health problem is more complicated due to high cost of living, low production and preservation of agricultural produce, economic recession with its resultant food insecurity (Okoh, 1998). The effect leads greater percentage of the populace to depend on junk foods and/or snacks. Increased rate of snack (especially cookies) in Nigeria has been reported as remote cause of increasing urbanization, working mothers and prolonged stay in school period (Onyechi and Afieroho, 2017). Snack is defined as a portion of processed food taken or eaten between meals (Carroll, 2013). Children snack up to three times per day, providing more than $27 \%$ of their total daily calories (Piernas and Popkins, 2010). Snacking frequency among adults has been reported to be two or more times daily, which contributes about $24 \%$ of total daily calories (Sebastian et al., 2011). Research suggests that people who are obese snack more frequently (Bertéus et al., 2005). A recent study revealed that school children that snack more than twice are likely to be overweight than those who consumed the fewest snacks (Gonzalez-Suarez et al., 2013). This is because the caloric contributions of most snacks are greater than foods eaten at meals because they contain high quantities of oil and carbohydrates (Bertéus et al., 2005).

However, snack can also be used to improve the nutritional status of people by substitute wheat flour with legumes, fruits, vegetable and nuts. According to Zizza and Xu (2012) snacking was associated with more nutrient-dense diets as measured by the USDA Healthy Eating Index-2005 scores. Also, another study observed the nutritional advantages of snacking which include improved micronutrient intake among populations at risk of nutritional deficiency (Kerve et al., 2006). Unhealthy snacks consumption can predispose individuals to the development of type 2 diabetes because they contain high level of simple carbohydrate and sugars which are linked to insulin resistance and type 2 diabetes mellitus, cardiovascular diseases and other diet related chronic diseases. Snacks can be used to increase the nutritional status of consumer by incorporating nutrient such as protein and fibre from plant sources which have health benefits (Zazueta-Morales et al., 2001).

The high price of wheat flour has necessitated the use of composite flour in bakery industry. Food crops like cereals (Usman et al., 2015), legumes (Grnah et al., 2014; Omah and Okafor, 2015; Noor-Azizah et al., 2012), fruit (Sengev et al., 2015), vegetables (Akoja and Coker, 2018; Kiin-Kabari et al., 2017; Amadi, 2017), seeds (Amadi and Ezenwa, 2019) and nuts (Nzeagwu and Onwudiwe, 2016) have been used in biscuit or cookies production. This promotes value addition to the food crops in question as regards to income generation, protein intake, food diversification and security and reduction on wheat importation.

Okra (Abelmoschus esculentus) is known in many English-speaking countries as ladies' fingers or ochro, is a flowering plant in the mallow family. It is valued for its edible green seed pods. The geographical origin of okra is disputed, with supporters of West African, Ethiopian, and South Asian origins (NRC, 2016). Okra has found medical application as a plasma replacement or blood volume expander (Adetuyi et al., 2008). It is also good source of iodine which is useful in the treatment of simple goiter and source of other medically useful compound (Moaward et al., 2014). Okra contains good quantities of minerals like iron, calcium, 
phosphorous, vitamins and phytochemicals (USDA, 2019). Cereals grains are staple foods like wheat, millet, sorghum, oat and maize of Nigerian populace and contribute about $73 \%$ of plant produce globally (Charalampopoulos et al., 2002). They are useful in breakfast cereals, noodle pasta, biscuit, bread and wine production (Katina et al., 2005). Cereals are good sources of both macro and micronutrient (McKevith, 2004) and phytochemicals (Flight and Clifton, 2006). They are also good in the prevention of diseases like cardiovascular and diabetes mellitus (Veen and Mann, 2004). There is scarcity of information on production of biscuits using okra- wheat composite flours. Therefore, this study sought to evaluate the nutrient, phytochemical and sensory properties biscuits produced from composites flours of wheat enriched with okra pod.

\section{MATERIALS AND METHODS}

\section{Procurement of samples}

Wheat flour, fresh okra pods together with the ingredients used in biscuit making such as baking powder, sugar, canola oil, milk powder, egg and flavours were purchased from Relief market Owerri, Imo State.

\section{Sample preparation}

\section{Processing of okra pod}

Two hundred grams of okra pod was sorted, washed, sliced into pieces, oven dried at $70^{\circ} \mathrm{C}$ for 8 hours and milled into flour.

\section{Sample formulation}

The biscuits were formulated as 100\% wheat flour (WF), $80 \%$ wheat flour : $20 \%$ okra pod flour (WOF1), 70\% wheat flour : 30\% okra pod flour (WOF2) and 60\% wheat flour : 40\% okra pod flour (WOF3).

\section{Recipe for biscuit making}

\section{Ingredients}

The recipe according to Pickett (2005) was adopted with little modification. The ingredients include $200 \mathrm{~g}$ of wheat/okra, 1 large egg, 1tsp of vanilla flavour, $50 \mathrm{ml}$ of canola oil, $50 \mathrm{~g}$ of powdered milk, $30 \mathrm{~g}$ of date palm, and $1 / 2$ tsp salt.

\section{Method of biscuit production}

The oil and date palm were mixed in a bowl and creamed until the mixture became light and fluffy. One large egg and milk was added to the cream while mixing. After 40 minutes of mixing, wheat flour and okra pod flour, vanilla flavour, baking powder and salt were slowly introduced into the mixture one after the other. The dough obtained was rolled on a flat rolling board sprinkled with flour to a uniform thickness using wooden rolling pin. Biscuit cutter was used to cut the dough into fine shapes and placed on well-greased baking trays. It was baked in an electric oven at $1000^{\circ} \mathrm{C}$ for 20 minutes until they are pale brown in colour. 


\section{Chemical analysis}

The proximate compositions of the biscuits were determined as described by (AOAC, 2005). Protein was determined by Kjeldahl method, fat was determined by Soxhlet extraction method, ash was determined by weighing $1 \mathrm{~g}$ of each sample into a tarred porcelain crucible. It was incinerated at $600^{\circ} \mathrm{C}$ for six hours in an ashing muffle furnace until ash was obtained. Moisture was determined by hot air oven method. Carbohydrate was determined by difference; moisture + protein + ash + fat $-100=\%$ carbohydrate. Phosphorus, magnesium, iron, calcium, and zinc were determined using atomic absorption spectrophotometer according to Ranjiham and Gopa (1980), potassium and manganese was determined using flame photometer according to AOAC (2005). Tannin was determined using folin-Denis spectrophotometric method according to Pearson (1979), phenol was determined using Folin-Ciocatean spectrophotometric method according to AOAC (33) while oxalate was determined as described by AOAC (2005).

\section{Sensory evaluation of the enriched biscuits}

Sensory attributes (color, crispness, aroma, taste and general acceptability) of the cookies were evaluated using a nine point hedonic scale with 9 as likes extremely and 1 as disliked extremely (Onwuka, 2005). Twenty undergraduate students of Nutrition and Dietetics Department Faculty of Health Sciences, Imo State University were randomly selected. They were provided with a glass of water to rinse their mouth after each tasting.

\section{Statistical analysis}

Data obtained was subjected to analysis of variance (ANOVA) and Turkey's test was used separate the means using using Statistical Product for Service and Solution (SPSS) version 21.

\section{RESULTS}

\section{Proximate and energy composition of the enriched biscuits}

Biscuit WOF3 had the highest moisture $(9.56 \pm 1.16 \%)$, ash $(3.49 \pm 0.01 \%)$, fibre $(5.62 \pm 0.09 \%)$ and protein $(14.99 \pm 1.38 \%)$ contents, biscuit WF was highest in fat $(15.68 \pm 0.22 \%)$, carbohydrate $(65.03 \pm 0.32 \%)$ and energy $(439.08 \pm 2.93 \mathrm{kcal})$ (Table 1$)$. Ash and fibre content were significantly $(\mathrm{p}<0.05)$ different among the samples. Fat and carbohydrate were significantly different except in biscuit WOF1 and WOF2 (fat) and biscuit WOF2 and WOF3 (carbohydrate) that did not differ significantly $(\mathrm{p}>0.05)$.

\section{Mineral composition of the enriched biscuits}

The table 2 shows the mineral composition of the biscuits. Biscuit WOF3 recorded the highest calcium $(212.50 \pm 0.01 \mathrm{mg} / 100 \mathrm{~g})$, magnesium $(83.50 \pm 0.09 \mathrm{mg} / 100 \mathrm{~g})$, potassium $(594.00 \pm 0.03$ $\mathrm{mg} / 100 \mathrm{~g})$, phosphorus $(1307.30 \pm 0.08 \mathrm{mg} / 100 \mathrm{~g})$ and manganese $(1457.00 \pm 0.24 \mathrm{mg} / 100 \mathrm{~g})$. The highest iron $(109.12 \pm 0.88 \mathrm{mg} / 100 \mathrm{~g})$ and copper $(23.00 \pm 0.42 \mathrm{mg} / 100 \mathrm{~g})$ contents were observed Journal of the Faculty of Agriculture and Veterinary Medicine, Imo State University Owerri website: www ajol.info 
in biscuit WOF1 while biscuit WOF2 has the highest zinc $(9.95 \pm 0.14)$ content. Enriched biscuits samples were significantly $(\mathrm{p}<0.05)$ different among the minerals except in iron where biscuit WOF2 and WOF3 were not significantly $(\mathrm{p}>0.05)$ different.

\section{Phytochemical composition of the enriched biscuits}

Phytochemical content of the enriched biscuits were presented in table 3 below. Biscuit WOF3 had the highest tannin $(0.81 \pm 0.96 \mathrm{mg} / 100 \mathrm{~g})$ and oxalate $(0.95 \pm 0.04 \mathrm{mg} / 100 \mathrm{~g})$ content while biscuit WOF2 was highest phenol $(1.41 \pm 0.001 \mathrm{mg} / 100 \mathrm{~g})$ content. Phenol content differed significantly $(\mathrm{p}<0.05)$ among the biscuit samples.

\section{Sensory evaluation of the enriched biscuits}

Sensory evaluation of the enriched biscuits shows that aroma (6.46 \pm 1.63$)$, colour $(5.66 \pm 1.68)$, taste (7.54 \pm 1.69$)$, and general acceptability $(5.94 \pm 1.73)$ was rated best in biscuit WOF3 while biscuit WOF1 rated best in crispness (7.66 \pm 1.89$)$. However, biscuit WF (100\% wheat flour) significantly $(\mathrm{p}<0.05)$ rated best in all the sensory attributes. Enriched biscuits were significantly $(\mathrm{p}<0.05)$ lower than the $100 \%$ wheat biscuit $(\mathrm{WF})$.

\section{DISCUSSION}

\section{Proximate composition of the enriched biscuits}

The moisture content of the enriched biscuits increased as varying degrees of okra flour was added. The moisture content of enriched biscuits was significantly lower $(\mathrm{p}<0.05)$ than 17.01 to 26.23\% reported by Akoja and Coker (2018) on wheat flour biscuit incorporated with okra powder and Sengev et al. (2015) which ranged from 7.9 to $10.0 \%$ on cookies produced from sweet potato and mango mesocarp flours. The present study was similar with Kinn-Kabiari et al. (2017) and Amadi (2017) that reported a low moisture content of ... and 5.67 to $6.12 \%$ respectively. The ash content of the enriched biscuits also increased on addition of varying degrees of okra flour. The study agrees with Akoja and Coker (2018) who also observed an increased ash content on addition of okra flour $(0.91-4.17 \%)$. Usman et al. (2015) reported similar increase in ash content $(0.52-1.12 \%)$ as carrot extract was added at varying degrees to wheat and maize flour composite blends. Vegetables are rich source of minerals in human diet. Ash content of a food material is a measure of nutritionally essential minerals present in that food material. High ash content in the biscuits signifies higher mineral content.

The protein content of the enriched biscuit increased on addition of okra pod flour and was consistent with (Akoja and Coker (2018). Also carrot vegetable increased the protein content 11.4 to $23.2 \%$ ) of biscuit (Usman et al., 2015). The protein content of the enriched biscuit was higher than 5.1 to $9.5 \%$ on cookies produced from mango mesocarp (Sengev et al., 2015), 6.88 $11.45 \%$ protein content from biscuits made from lentil seed and wheat flour blends (Grah et al., 2014) and $8.12-8.40 \%$ from cookies with different levels of eggplant flour substitution (Uthumporm et al., 2015). The difference in the protein content could be attributed to different Journal of the Faculty of Agriculture and Veterinary Medicine, Imo State University Owerri website: www ajol.info 
vegetable sources that have varying protein levels and/or recipe used. Protein is needed in the body for the growth and repair of worn out tissues, forms major enzymes and hormones and boosts the immune system.

The fat content of the cookies reduced on addition of okra flour. This shows that okra pod flour is a low fat vegetable. Akoja and Coker (2018) and Kinn-Kabiari et al. (2017) reported fat content of 17.90 to $20.79 \%$ and 19.06 to $20.32 \%$ which reduced on addition of okra pod flour but their results were significantly higher $(\mathrm{p}<0.05)$ than that obtained from the present study. The difference may be as a result of recipe used. The present study used canola oil, a polyunsaturated oil and in small quantity too. The use of margarine and fat in bakery also predisposes consumers to high intake of fat. However, Ajibola et al. (2015) who worked on whole wheat biscuits incorporated with moringa flour and cocoa powder reported fat content 13.19 to $15.00 \%$ which agreed with that obtained from the present study. Fat is required for the metabolism of fat soluble vitamins such as vitamin $\mathrm{A}, \mathrm{D}, \mathrm{E}$ and $\mathrm{K}$ and it also forms hormones systems in the body.

The crude fiber content of the enriched biscuit increased on okra pod flour addition. This was consistent with previous studies (Akoja and Coker 2018; Kinn-Kabiari et al., 2017; Grah et al., 2014). Fiber increases bulk of food and aids digestion of food. It is very essential component of food and can help stop constipation. Carbohydrate content of the enriched biscuit reduced on addition of okra pod flour. The present study was consistent with (Akoja and Coker 2018; Ajibola et al., 2015) but lower than 62.32 - 70.01\% reported by Omah and Okafor (2015) on legume based cookies. This shows that vegetable sources have lower carbohydrate contents compared to legumes. The energy content of the cookies reduced on addition of okra pod flour and was consistent with 419.06 - 455.05kcal reported by (Akoja and Coker 2018) on wheat flour biscuit incorporated with Okra powder. However, Grah et al. (2014) reported that energy content of cookies increased on addition of lentil seed flour to wheat flour and Sengev et al. (2015) stated that energy content increased from 394 to $410 \mathrm{kcal}$ on addition of sweet potato flour and mango mesocarp flour to wheat flour.

\section{Mineral composition of the cookies}

Calcium, magnesium, potassium, manganese and phosphorous content of the enriched biscuit increased on okra pod substitution and were highest in biscuit WOF3. Also biscuit WOF2 was highest for zinc while biscuit WOF1 was highest for iron and copper contents. This shows that okra pod is a good source of micronutrients. The study was similar with (Usman et al., 2015; Noor-Aziah et al., 2012; Ajoka and Coker, 2018). However, some studies reported lower values on addition of legumes (Noor-Aziah et al., 2012; Ndife et al., 2014), vegetables (Kinn-Kabiari et al., 2017; Dooshima et al., 2016), and nuts (Nzeagu and Onwudiwe, 2016).

\section{Phytochemical composition of enriched biscuit}

All the enriched biscuits recorded lower tannin values, although they increased on addition of okra pod flour. However, the tannin values are still within permissible limits of $0.05 \%-0.2 \%$ (5 
to $20 \mathrm{mg} / 100 \mathrm{~g}(42,43)$. The phenol values of the cookies increased on addition of okra pod flour. However results were consistent with that reported by Nzeagwu and Onuwudiwe (41). The oxalate values fluctuated on addition of okra pod flour. However, the oxalate values obtained were below permissible limits ( 3 to $5 \mathrm{mg} / \mathrm{kg}$ ) by Schiavone et al. (43). The study was consistent with $(0.45$ to $0.78 \mathrm{mg} / 100 \mathrm{~g})$ reported by Nzeagwu and Onuwudiwe (41) on cookies made from tiger nut flour. The phenolic content of the cookies obtained from the present study was consistent with 0.51 to $1.24 \mathrm{mg} / \mathrm{g}$ and 0.21 to $2.35 \mathrm{mg} / \mathrm{g}$ reported by Kinn-Kabiari et al. (19) and Grah et al. (14). But lower values ranging from 0.11 to $0.84 \mathrm{mg} / 100 \mathrm{~g}$ was reported by Omah and Okafor (2015). Phenols have been reported to have antioxidant and antimicrobial activity and can help fight against inflammation, degenerative diseases and allergies.

\section{Sensory evaluation of the cookies}

The sensory evaluation obtained from the present study was in agreement with that reported by (Nzeagu and Onwudiwe, 2016). The aroma attribute was similar with (Akoja and Coker, 2018; Kinn-Kabari et al., 2017). The colour of the cookies reduced on addition of okra pod flour and results obtained were lower than those reported by (Omah and Okafor, 2015; Ajibola et al., 2015). The taste of the enriched biscuit was in agreement with previous studies reported by (Akoja and Coker, 2018; Schiavone et al., 2007) on biscuits made from wheat and moringa composite flour and cookies produced from wheat flour supplemented with okra pod flour respectively. The texture of the enriched biscuit agrees with work (Akajiaku et al., 2018). Crispness of the enriched biscuit reduced on okra flour addition. The decrease in crispiness with increased substitution levels may be as a result of moisture uptake by okra pod flour. It has been reported that moisture uptake leads to loss of crispness of food products (Gernah et al., 2013), and this was consistent with (Sengev et al., 2015). The overall acceptability rating of the cookies was observed in the control biscuit. This was because the judges were familiar with the product. However, enriched biscuit WOF4 was rated best among the biscuits.

\section{CONCLUSION}

Nutritional and phytochemical composition of biscuits enriched with okra pod flour was highly improved. Acceptable biscuits were produced from both the enriched biscuit. Biscuit WOF3 with 60 (wheat):40 (okra) was best rated with increased protein, ash, fibre and minerals when compared with other biscuits formulated. Therefore, enrichment of biscuits with okra should be encouraged as it gives value addition to the vegetable as well as improving nutritional quality of confectionaries. 


\section{REFERENCES}

Adetuyi, F.O., Osagie, A.U. and Adekunle, A.T. (2008). Effect of Postharvest Storage Techniques on the Nutritional Properties of Benin Indigenous Okra Abelmoschus esculentus (L) Moench. Pakistan Journal of Nutrition; 7: 652-657.

Ajibola, F. C. Oyerinde, V. O. and Adeniyan, O. S. (2015). Physicochemical and Antioxidant Properties of Whole-Wheat Biscuits Incorporated with Moringa oleifera Leaves and Cocoa Powder. Journal of Scientific Research and Reports; 7(3): 195-206.

Akajiaku, L.O., Kabuo, N.O., Alagbaoso, S.O., Orji, I.G. and Nwogu, A.S. (2018). Proximate, Mineral and Sensory Properties of Cookies Made from Tiger-Nut Flour;2 (1): 1 - 5.

Akoja, S.S. and Coker, O.J. (2018). Physicochemical, functional, pasting and sensory properties of wheat flour biscuit incorporated with Okra powder. International Journal of Food Science and Nutrition; 3 (5): 64-70. ISSN: 2455-4898

Amadi, Joy. A.C and Ezenwa, C. (2019). Nutrient evaluation and acceptability of cookies produced from wheat flour, tiger nut milk and fermented jack fruit seeds (Artocarpus heterophyllus). Elixir Food Science; 127: 52710 -52715.

Amadi, Joy. A.C. (2017). Production, chemical and sensory evaluation of cookies fortified with moringa oleifera leaves. Journal of Dietitians Association of Nigeria; 8: 96-103.

Association of analytical chemists (AOAC) (2005). Official methods of analysis of the AOAC International. $15^{\text {th }}$ ed DC, USA.

Bertéus, F. H., Torgerson, J.S, Sjöström, L. and Lindroos, A.K. (2005). Snacking frequency in relation to energy intake and food choices in obese men and women compared to a reference population. International Journal of Obesity; 29 (6):711-719.

Carroll, A. (2013). "How Snacking Became Respectable". Wall Street Journal. ISSN 0099-9660. Retrieved 2016-05-29.

Charalampopoulos, D., Pandiella, S., and Webb, C. (2002). Growth studies of potentially probiotic lactic acid bacteria in cereal-based substrate. Journal of Applied Microbiology; 92(5): 851-859. Doi 10.1046/j.1365-2672.2002.01592.x.. 
Dooshima, I. B., Dabels N., Amove J. and Iorliam B. (2016): Nutritional Composition, Physical and Sensory Properties of Cookies from Wheat, Acha and Mung Bean Composite Flours. International Journal Nutrition and Food Sciences; 5 (6): 401-406.

Flight, I., and Clifton, P. (2006). Cereals grains and legumes in the prevention of coronary heart disease and stroke: A review of the literature. European Journal of Clinical Nutrition; 60(10):1145-1159. http://www.nature.com/ejcn/journal/v60/n10/pdf/1602435a.pdf.

Gernah, D.I., Ikya, J.K. and Lawrence, M. (2013). Chemical properties of sorghum/moringa seed composite flours and acceptability of their gruels. Nigerian Journal of Nutritional Sciences, 34(2):127- 131.

Gonzalez-Suarez, C.B., Lee-Pineda, K., Caralipio, N.D., Grimmer-Somers, K., Sibug, E.O. and Velasco, Z.F. (2013). Is what Filipino children eat between meals associated with body mass index? Asia Pacific Journal of Public Health; 7 (4): 23 - 29.

Grah, B. A M, Yapo, B. M., Dakia, A.P, Niaba, K. and Gnakri, P.V.D. (2014). Manufacture of Biscuit from the Flour Of Wheat Andlentil Seeds as a Food Supplement. European Journal of Food Science and Technology; 2 (2): 23-32

Katina, K., Arendt, E., Liukkonen, K.H., Autio, K., Flander, L. and Poutanen, K. (2005). Potential of sourdough for healthier cereals products. Trends in Food Science and Technology; 16: (1-3): 104-112. http://dx.org/10.1016/j.tifs.2004.03.008.

Kerver, J.M., Yang, E.J., Obayashi, S., Bianchi, L. and Song, W.O. (2006). Meal and snack patterns are associated with dietary intake of energy and nutrients in US adults. Journal of American Dietetic Association; 106 (1):46-53.

Kiin-Kabari, D.B., Emelike, N.J.T. and Ebere, C.O. (2017). Influence of drying techniques on the quality characteristics of wheat flour cookies enriched with moringa (Moringa oleifera) leaf powder. International Journal of Food Science and Nutrition; 2 (3): 94-99.

McKevith, B. (20040. Nutritional aspects of cereals. Nutrition Bulletin, 29(2): 111-142. Doi: 10.1111/j.1467-3010-2004.00418.

Moaward, F.G., Abdelwhab, B.M., Abdelnahun, F.M. and Shehaya, F.W. (2014). Okra origins Annals of Agricultural science; 21: 603 - 613.

National Research Council (2006). "Okra". Lost Crops of Africa: Volume II: Vegetables. Lost Crops of Africa. 2. National Academies Press. ISBN 978-0-309-10333-6. Retrieved 201807-7. 
Ndidi, U. S., Ndidi, C. U., Abbas, O., Aliyu, M., Francis, G. B., and Oche, O. (2014). Proximate, antinutrients and mineral composition of raw and processed (Boiled and Roasted) Sphenostylis stenocarpa seeds from Southern Kaduna, Northwest Nigeria. http://dx.doi.org/10.1155/2014/280837

Ndife, J., Koda, F., and Fagbemi, S. (2014). Production and quality assessment of enriched cookies from whole wheat and full fat soya. European Journal of Food Science and Technology; 2: 19-28

Noor Aziah, A. A., Mohamad Noor, A. Y. and Ho, L.H. (2012). Physicochemical and organoleptic properties of cookies incorporated with legume flour. International Food Research Journal; 19 (4): 1539-1543. http://www.ifrj.upm.edu.my

Nwakalor, Chizoba N. (2014). Sensory Evaluation of Cookies Produced from Different Blends of Wheat and moringa Oleifera Leaf Flour. International Journal of Nutrition and Food Sciences; 3 (4):307-310. doi: 10.11648/j.ijnfs.20140304.21.

Nzeagwu, O.C. and Onuwudiwe, E.T. (2016). Nutrient composition and sensory properties of tiger nut (Cyperus esculentus) biscuit. Nigerian Journal of Nutritional Sciences; 37 (1): 157-164

Okoh, N.P (1998). Cereal grains, In nutritional quality of plant foods, Osagie, A.O. and Eka, O.U. Post harvest research unit Benin city.

Omah, E.C. and Okafor, G.I. (2015). Selected Functional Properties, Proximate Composition of Flours and Sensory Characteristics of Cookies from Wheat and Millet-Pigeon Pea Flour Blends. Pakistan Journal of Nutrition; 14 (9): 581-585. ISSN 1680-5194 @ Asian Network for Scientific Information.

Onwuka, G.I. (2005). Food Analysis and Instrumentation Theory and Practice. Naphtali Print, Lagos, Nigeria: $81-90$.

Onyechi, A.U. and Afieroho, M.C. (2017). Comparative proximate and qualitative phytochemical evaluation of three species of oyster mushrooms cultivated in Nigeria. Journal of Dietitians Association of Nigeria; 8:90-95.

Oshionya, U.G., Anyika, J., Nwachukwu, C. and Olebu, J.E. (2015). Effect of processing on the nutritional content and acceptability of African yam bean (AYB) (Sphenostylis Stenocarpia). Journal of Dietitians Association of Nigeria; 6: 1-6.

Pearson, D. (1979). The Chemical Analysis of foods. $8^{\text {th }}$ ed. Churchill Livingstone, Edinburg. 
Journal of Agriculture and Food Sciences

Volume 17 Number 1, April 2019 pp $65-78$

Amadi, Joy A. C. 75

Pickett, J. (2005). Basic Biscuit. Retrieved from http://www.allrecipes.com/recipe/basicbbiscuits.

Piernas, C. and Popkin, B.M. (2010). Snacking increased among U.S. adults between 1977 and 2006. Journal of Nutrition; 5 (2):325 - 330.

Ranjihm, S.K. and Gopal, K. (1980). Wet chemical digestion of biological materials for mineral analysis. In: Laboratory manual for nutrition research Vikas Pub. House PVT Ltd, New Delhi India.

Schiavone, A., Guo, K., Tassone, S., Gasco, L., Hermandez, E., Denti, R., and Zoccarate, I. (2007). Effects of a natural extract of chestnut wood on digestibility, performance traits, and nitrogen balance of broiler chicks. Poultry Science; 87: 521-527.

Sebastian, R.S., Wilkinson, E. C. and Goldman, J.D. (2011). Snacking Patterns of U.S. Adults: What We Eat in America, NHANES 2007-2008. Food Surveys Research Group Dietary Data Brief No. 4.

Sengev, I.A., Gernah, D.I. and Bunde-Tsegba1, M.C. (2015). Physical, Chemical And Sensory Properties Of Cookies Produced From Sweet Potato And Mango Mesocarp Flours. African Journal of Food, Agriculture, Nutrition and Development; 15 (5) ISSN 16845374.

USDA (United States Department of Agricultural Research Service National Nutrient Database for Standard References Release 28. https://ndb.nal.usda.gov/ndb/ (Accessed 15/02/2019).

Usman, G.O., Ameh, U.E, Alifa, O.N. and Babatunde, R.M. (2015). Proximate Composition of Biscuits Produced from Wheat Flour and Maize Bran Composite Flour Fortified with Carrot Extract. Journal of Nutrition and Food Sciences; 5: (5). DOI: 10.4172/21559600.1000395. ISSN: 2155-9600.

Uthumporn, U. Woo, W.L. Tajul, A.Y. and Fazilah, A. (2015) Physico-chemical and nutritional evaluation of cookies with different levels of eggplant flour substitution, CyTA - Journal of Food Science 13:2, 220-226. DOI: 10.1080/19476337.2014.942700

Venn, B., and Mann, J. (2004). Cereals grains, legumes and diabetes. European Journal of Clinical Nutrition; 58 (11): 1443-1461. Dio.10.1038/sj.ejcn.1601995.

World Food Programme (2011). Hunger 100ms Amidst Drought in the horn of Africa (Available from http://www.WFP.org/stories/hunger-100ms-amld drought-horn-African gclid=Cl6nj 5 Cy76k CF Q8qAod RH 8 X ZA) (Accessed online on $20^{\text {th }} 2$, 2019). 
Journal of Agriculture and Food Sciences

Amadi, Joy A. C. 76

Volume 17 Number 1, April 2019 pp $65-78$

Zazueta-Morales, J. J., Martínez-Bustos, F., Jacobo- Valenzuela, N., Ordorica-Falomir, C. and Paredes-López, O. (2001). Effect of the addition of calcium hydroxide on some characteristics of extruded products from blue maize (Zea mays L.) using response surface methodology. Journal of the Science of Food and Agriculture; 81, 1379-1386. http://dx.doi.org/10.1002/jsfa.951

Zizza, C.A. and Xu, B. (2012). Snacking is associated with overall diet quality among adults. Journal of the Academy of Nutrition and Dietetics; 112 (2):291-296. 
Table.1: Proximate and energy composition of the enriched biscuits

\begin{tabular}{lcccc}
\hline Proximate (\%) & Biscuits WF & Biscuits WOF1 & Biscuits WOF2 & Biscuits WOF3 \\
\hline Moisture & $3.19^{\mathrm{a}} \pm 0.46$ & $4.52^{\mathrm{a}} \pm 1.72$ & $9.08^{\mathrm{b}} \pm 0.45$ & $9.56^{\mathrm{b}} \pm 1.16$ \\
Ash & $1.89^{\mathrm{a}} \pm 0.02$ & $2.99^{\mathrm{b}} \pm 0.01$ & $2.87^{\mathrm{c}} \pm 0.02$ & $3.49^{\mathrm{d}} \pm 0.01$ \\
Protein & $11.45^{\mathrm{a}} \pm 2.05$ & $12.48^{\mathrm{a}} \pm 0.10$ & $13.65^{\mathrm{a}} \pm 0.62$ & $14.99^{\mathrm{a}} \pm 1.38$ \\
Fat & $15.68^{\mathrm{c}} \pm 0.22$ & $14.49^{\mathrm{b}} \pm 0.77$ & $14.72^{\mathrm{b}} \pm 0.17$ & $12.69^{\mathrm{a}} \pm 0.25$ \\
Crude fibre & $2.73^{\mathrm{a}} \pm 0.05$ & $3.80^{\mathrm{b}} \pm 0.03$ & $4.85^{\mathrm{c}} \pm 0.07$ & $5.62^{\mathrm{d}} \pm 0.09$ \\
Carbohydrate & $65.03^{\mathrm{c}} \pm 0.32$ & $61.69^{\mathrm{b}} \pm 0.80$ & $54.79^{\mathrm{a}} \pm 0.37$ & $53.63^{\mathrm{a}} \pm 0.37$ \\
Energy (kcal) & $439.08^{\mathrm{a}} \pm 2.93$ & $427.24^{\mathrm{a}} \pm 1.59$ & $402.34^{\mathrm{a}} \pm 3.14$ & $348.75^{\mathrm{a}} \pm 2.96$ \\
\hline
\end{tabular}

Means are values of triplicate determinations. Mean values with different superscripts in the same row are significantly different $(\mathrm{p}<0.05)$. Biscuit WF: Wheat Flour (control) 100\%, Biscuit WOF1: Wheat 80\% - Okra 20\%-Flour, Biscuit WOF2: Wheat 70\% - Okra 30\% - Flour, Biscuit WOF3: Wheat 60\% - Okra 40\% - Flour.

Table 2: Mineral composition of the enriched biscuits

\begin{tabular}{lrrrr}
\hline $\begin{array}{l}\text { Minerals } \\
(\mathbf{m g} / \mathbf{1 0 0 g})\end{array}$ & Biscuits WF & Biscuits WOF1 & Biscuits WOF2 & Biscuits WOF3 \\
\hline Calcium & $85.00^{\mathrm{a}} \pm 0.01$ & $139.50^{\mathrm{b}} \pm 0.14$ & $171.50^{\mathrm{c}} \pm 0.12$ & $212.50^{\mathrm{d}} \pm 0.10$ \\
Magnesium & $44.50^{\mathrm{a}} \pm 0.07$ & $66.00^{\mathrm{b}} \pm 0.05$ & $74.00^{\mathrm{c}} \pm 0.08$ & $83.50^{\mathrm{c}} \pm 0.09$ \\
Potassium & $545.00^{\mathrm{c}} \pm 0.64$ & $326.00^{\mathrm{a}} \pm 0.01$ & $420.50^{\mathrm{b}} \pm 0.01$ & $594.00^{\mathrm{c}} \pm 0.03$ \\
Manganese & $925.00^{\mathrm{a}} \pm 0.21$ & $967.00^{\mathrm{a}} \pm 0.17$ & $1240.00^{\mathrm{b}} \pm 0.28$ & $1457.00^{\mathrm{c}} \pm 0.24$ \\
Iron & $85.05^{\mathrm{a}} \pm 0.49$ & $109.12^{\mathrm{c}} \pm 0.88$ & $92.65^{\mathrm{b}} \pm 0.56$ & $94.15^{\mathrm{b}} \pm 0.63$ \\
Copper & $6.20^{\mathrm{b}} \pm 0.07$ & $23.00^{\mathrm{d}} \pm 0.42$ & $1.72^{\mathrm{a}} \pm 0.10$ & $7.20^{\mathrm{c}} \pm 0.14$ \\
Zinc & $4.26^{\mathrm{a}} \pm 0.11$ & $7.72^{\mathrm{b}} \pm 0.09$ & $9.95^{\mathrm{d}} \pm 0.14$ & $8.37^{\mathrm{c}} \pm 0.10$ \\
Phosphorus & $1207.75^{\mathrm{c}} \pm 0.10$ & $934.15^{\mathrm{a}} \pm 0.26$ & $1013.90^{\mathrm{b}} \pm 0.11$ & $1307.30^{\mathrm{d}} \pm 0.08$ \\
\hline
\end{tabular}

Means are values of triplicate determinations. Mean values with different superscripts in the same row are significantly different $(\mathrm{p}<0.05)$. Biscuit WF: Wheat Flour (control) 100\%, Biscuit WOF1: Wheat 80\% - Okra 20\%- Flour, Biscuit WOF2: Wheat 70\% - Okra 30\% - Flour, Biscuit WOF3: Wheat 60\% - Okra 40\% - Flour. 
Volume 17 Number 1, April 2019 pp $65-7.8$

Table 3: Phytochemical composition of the enriched biscuits

\begin{tabular}{lllll}
\hline $\begin{array}{l}\text { Phytochemical } \\
(\mathbf{m g} / \mathbf{1 0 0 g})\end{array}$ & Biscuits WF & Biscuits WOF1 & Biscuits WOF2 & Biscuits WOF3 \\
\hline Tannin & $0.16^{\mathrm{a}} \pm 0.07$ & $0.22^{\mathrm{a}} \pm 0.025$ & $0.19^{\mathrm{a}} \pm 0.07$ & $0.81^{\mathrm{a}} \pm 0.96$ \\
Phenol & $0.71^{\mathrm{a}} \pm 0.05$ & $1.16^{\mathrm{c}} \pm 0.05$ & $1.41^{\mathrm{d}} \pm 0.01$ & $1.01^{\mathrm{b}} \pm 0.22$ \\
Oxalate & $0.84^{\mathrm{a}} \pm 0.04$ & $0.80^{\mathrm{a}} \pm 0.11$ & $0.81^{\mathrm{a}} \pm 0.96$ & $0.95^{\mathrm{b}} \pm 0.04$ \\
\hline
\end{tabular}

Means are values of triplicate determinations. Mean values with different superscripts in the same row are significantly different $(\mathrm{p}<0.05)$. Biscuit WF: Wheat Flour (control) 100\%, Biscuit WOF1: Wheat 80\% - Okra 20\%- Flour, Biscuit WOF2: Wheat 70\% - Okra 30\% - Flour, Biscuit WOF3: Wheat 60\% - Okra 40\% - Flour.

Table 4: Sensory evaluation of the enriched biscuits

\begin{tabular}{lllll}
\hline Sensory Parameters & Biscuits WF & Biscuits WOF1 & Biscuits WOF2 & Biscuits WOF3 \\
\hline Aroma & $7.34^{\mathrm{b}} \pm 1.72$ & $6.54^{\mathrm{a}} \pm 1.68$ & $6.28^{\mathrm{a}} \pm 1.62$ & $6.46^{\mathrm{a}} \pm 1.63$ \\
Colour & $6.86^{\mathrm{b}} \pm 1.39$ & $5.38^{\mathrm{a}} \pm 1.49$ & $5.34^{\mathrm{a}} \pm 1.50$ & $5.66^{\mathrm{a}} \pm 1.68$ \\
Taste & $8.64^{\mathrm{b}} \pm 1.75$ & $7.24^{\mathrm{a}} \pm 1.62$ & $7.18^{\mathrm{a}} \pm 1.85$ & $7.54^{\mathrm{a}} \pm 1.69$ \\
Texture & $6.94^{\mathrm{b}} \pm 1.63$ & $6.14^{\mathrm{a}} \pm 1.37$ & $6.18^{\mathrm{a}} \pm 1.68$ & $6.90^{\mathrm{a}} \pm 1.37$ \\
Crispness & $8.64^{\mathrm{c}} \pm 1.87$ & $7.66^{\mathrm{b}} \pm 1.89$ & $7.02^{\mathrm{ab}} \pm 1.57$ & $6.82^{\mathrm{a}} \pm 1.82$ \\
Overall acceptability & $7.26^{\mathrm{c}} \pm 1.41$ & $5.64^{\mathrm{a}} \pm 1.97$ & $5.22^{\mathrm{a}} \pm 1.69$ & $5.94^{\mathrm{a}} \pm 1.73$ \\
\hline
\end{tabular}

Means are values of triplicate determinations. Mean values with different superscripts in the same row are significantly different $(\mathrm{p}<0.05)$. Biscuit WF: Wheat Flour (control) 100\%, Biscuit WOF1: Wheat 80\% - Okra 20\%- Flour, Biscuit WOF2: Wheat 70\% - Okra 30\% - Flour, Biscuit WOF3: Wheat 60\% - Okra 40\% - Flour. 